\title{
Analisis Penggunaan Metode Analitycal Hierarchy Process (AHP) dalam Pemberian Pembiayaan bagi Nasabah di BRI Syariah KCP Ujungberung
}

\author{
Iman yulianto \\ Prodi Hukum Ekonomi Syariah, Fakultas Syariah, Universitas Islam Bandung \\ Jl. Tamansari No. 1 Bandung 40116 \\ z278112214@gmail.com
}

\begin{abstract}
The application of AHP method in financing risk management and analysis efforts, especially for KURS program in BRI Syariah is implemented in the decision making system application that is built with PHP programming language and uses the "MySql" database application which is expected to create a system that can help the bank in determining KURS recipients. by online. But in the implementation of the application, the AHP analysis process at BRI Syariah can be said to be in harmony with the Maqashid of Sharia and the terms of the distribution of financing as stipulated in the applicable laws. Based on these problems, the authors compile the formulation of the problem as outlined in the form of questions as follows: What are the provisions of Islamic economics regarding the determination of the distribution of financing for customers in Islamic banks? How is the implementation of the analysis of determining the priority of financing for customers using the Analyticalcal Hierarchy Process (AHP) method at BRI Syariah Ujungberung KCP? And how is the analysis of sharia economics towards the determination of financing provision for customers using the Analitycal Hierarchy Process (AHP) method in BRI Syariah Ujungberung KCP? The research method used is a descriptive analysis research method that aims to describe the use of the AHP method in analyzing financing for the MSME sector in the KURS program at BRI Syariah Ujungberung KCP. The conclusion of this study is that the determination of financing distribution for customers in Islamic banks is implemented into the application of the precautionary principle by using elements of the 5C standard and Islamic economic principles such as the principles of openness, honesty and fairness. The financing analysis using the AHP method at BRI Syariah Ujungberung KCP is carried out systematically and conical so as to produce the right, proportional and efficient decisions. And the determination of financing for customers using the Analyticalcal Hierarchy Process (AHP) method in BRI Syariah Ujungberung $K C P$ in general is in accordance with the values and principles of economics in Islam which includes openness, fairness, prudence and openness and various aspects related to with human interests by providing for order in life and wellbeing (maslahah).
\end{abstract}

Keywords-Process, Analysis, Financing, and Islamic Banks.

Abstract-Penerapan metode AHP dalam upaya analisis dan manajemen risiko pembiayaan khususnya bagi program KURS di BRI Syariah diimplementasikan pada aplikasi sistem pengambilan keputusan yang dibangun dengan bahasa pemograman PHP dan menggunakan aplikasi database "MySql" yang diharapkan dapat membuat sistem yang dapat membantu pihak bank dalam menentukan penerima KURS secara online. Namun dalam pelaksanaan aplikasinya, prosesn analisa AHP di BRI Syariah ini bisa dikatakan selaras dengan maqashid syariah maupun ketentuan penyaluran pembiayaan sebagaimana yang diatur perundang-undangan yang berlaku. Berdasarkan permasalah tersebut, maka penulis menyusun rumusan masalah yang dituangkan ke dalam bentuk pertanyaan sebagai berikut : Bagaimana ketentuan ekonomi syariah tentang penetapan penyaluran pembiayaan bagi nasabah di bank syariah ? Bagaimana pelaksanaan analisis penentuan prioritas pemberian pembiayaan bagi nasabah dengan metode Analitycal Hierarchy Process (AHP) di BRI Syariah KCP Ujungberung? Dan bagaimana analisis ekonomi syariah terhadap penetapan pemberian pembiayaan bagi nasabah dengan metode Analitycal Hierarchy Process (AHP) di BRI Syariah KCP Ujungberung ? Metode penelitian yang digunakan adalah metode penelitian deskriptif analisis yang bertujuan untuk mendeskripsikan mengenai penggunaan metode AHP dalam melakukan analisis pembiayaan bagi sektor UMKM pada program KURS di BRI Syariah KCP Ujungberung. Simpulan dari penelitian ini adalah penetapan penyaluran pembiayaan bagi nasabah di bank syariah diimplementasikan ke dalam penerapan prinsip kehati-hatian dengan menggunakan unsur standar 5C dan prinsip ekonomi Islam seperti prinsip keterbukaan, kejujuran dan keadilan. Pelaksanaan analisis pembiayaan dengan metode AHP di BRI Syariah KCP Ujungberung dilakukan secara sistematis dan mengkrucut sehingga menghasil keputusan yang tepat, proporsional dan efisien. Serta Penetapan pemberian pembiayaan bagi nasabah dengan metode Analitycal Hierarchy Process (AHP) di BRI Syariah KCP Ujungberung secara umum telah sesuai dengan nilai-nilai dan prinsip-prinsi pekonomi dalam Islam yang meliputi keterbukaan, keadilan, kehatihatian dan keterbukaan serta berbagai aspek yang terkait dengan kepentingan manusia dengan menyediakan untuk ketertiban kehidupan dan kesejahteraan (maslahah).

Kata kunci-Proses, Analisia, Pembiayaan, dan Bank Syariah.

\section{PENDAhULUAN}

\section{A. Latar Belakang Masalah}

Perbankan syariah merupakan salah satu instrument keuangan yang berbasis pada syariat Islam. Tujuan ekonomi Islam adalah pencapaian maqshid syariah dengan cara mewujudkan keadilan dan keseimbangan masyarakat. Bank syariah merupakan sub-sistem ekonomi Islam. Maka seharusnya tujuan bank syariah adalah menjunjung tinggi 
tujuan sosial, mempromosikan nilai-nilai Islam kepada seluruh stakeholder, memberikan kontribusi kesejahteraan sosial, mendukung keberlangsungan ekonomi, dan berusaha mengentaskan kemiskinan.

Produk bank syariah memiliki peluang yang lebih luas dalam rangka memenuhi kebutuhan nasabah deposan maupun debitur sesuai dengan kebutuhan nyata mereka. Pada saat krisis ekonomi, sektor ini mampu tetap bertahan. Sektor UMKM mempunyai keunggulan dan sangat potensial untuk lebih dikembangkan melalui suatu kebijakan yang tepat dan dukungan dari lembaga yang tepat pula. Salah satu bank syariah yang memiliki produk pembiayaan bagi sektor UMKM adalah BRI Syariah melalui program atau produk pembiayaan yang diberi nama Kredit Usaha Rakyat Syariah (KURS).

Akan tetapi, fenomena yang terjadi di masyarakat, kemanfaatan bank syariah khususnya BRI Syariah bagi keberlangsungan ekonomi pada sektor UMKM belum dirasakan berpengaruh secara signifikan. Dalam hal ini, seakan BRI Syariah dibenturkan pada realita dimana pihak manajemen menuntut agar pembiayaan yang disalurkan memeliki peluang profit atau keuntungan laba yang besar, namun di sisi lain resiko menyalurkan pembiayaan pada sektor UMKM juga memiliki persentase resiko yang tinggi. penyaluran pembiayaan yang dilakukan BRI Syariah terhadap sektor UMKM dihadapkan pada risiko pembiayaan yang tinggi.

Terkait hal di atas, maka dalam mengupayakan pengamanan pembiayaan yang disalurkan kepada sektor UMKM tersebut, pihak manajemen BRI Syariah harus menerapkan metode analisis pembiayaan yang efektif dan efisien. Salah satu metode analisa pembiayaan yang terbilang komprehensif dalam menganalisa berbagai indikator risiko pembiayaan adalah melalui penerapan metode Analytical Hierarchy Process (AHP) yang merupakan metode sistematis dan berpengaruh terhadap setiap struktural yang mewakili dalam setiap hirarki atau jaringan pada kriteria-kriteria pengambilan keputusan dan dipecah menjadi bagian-bagian untuk memahami pentingnya setiap bagian dalam keseluruhan kriteria pengambilan keputusan. Pelaksanaan program KURS yang merupakan penyaluran pembiayaannya UMKM di BRI Syariah KCP Ujungberung juga menghadapi dilema dimana penyaluran pembiayaan pada sektor UMKM memiliki tingkat resiko yang tinggi. Oleh karena itu, pihak manajemen BRI Syariah KCP Ujungberung justru terkesan tidak optimal dalam memaksimalkan program KURS tersebut. Berdasarkan hal tersebut, maka pihak manajmen BRI Syariah KCP Ujungberung menerapkan metode AHP

\section{B. Tujuan Penelitian}

1. Untuk mengetahui pelaksanaan analisis penentuan prioritas pemberian pembiayaan bagi nasabah dengan metode Analitycal Hierarchy Process (AHP) di BRI Syariah KCP Ujungberung.
2. Untuk mengetahui analisis ekonomi syariah terhadap penetapan pemberian pembiayaan bagi nasabah dengan metode Analitycal Hierarchy Process (AHP) di BRI Syariah KCP Ujungberung.

\section{TINJAUAN PUSTAKA}

\section{A. Prosedur Penyaluran Pembiayaan di Bank Syariah}

Pembiayaan merupakan salah satu tugas pokok bank syariah dalam memenuhi kebutuhan pihak-pihak yang merupakan daficit unit. Dalam penyaluran pembiayaan tersebut, manajemen bank syariah harus melakukan analisa terlebih dahulu secara benar sesuai prinsip kehati-hatian bank atau prudential banking. Penerapan perinsip kehatihatian tersebut sesuai dengan ajaran nilai-nilai kataqwaan dalam Islam. Hal ini sebagaimana yang termaktub dalam Q.S Shaad ayat 24 sebagai berikut :

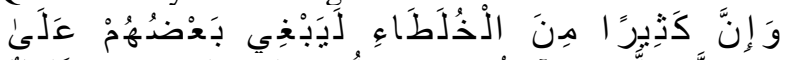

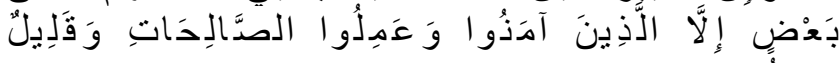

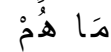

“... Dan sesungguhnya kebanyakan dari orang-orang yang berserikat itu sebahagian mereka berbuat zalim kepada sebahagian yang lain, kecuali orang-orang yang beriman dan mengerjakan amal shaleh dan amat sedikitlah mereka ini...".

Ayat di atas mengisyaratkan bahwa kegiatan "berserikat" yang dapat diartikan seperti kegiatan bisnis pada pembiayaan yang dilakukan bank syariah dapat menjadikan pihak-pihak yang terlibat berbuat zalim. Akan tetapi apabila hal ini dilakukan atas dasar amal shaleh dan sesuai ajaran Islam, maka kegiatan tersebut justru akan mendatangkan keberkahan. Dengan demikian, pelaksanaan analisa pembiayaan yang dilakukan bank syariah itu juga harus dilakukan sesuai ajaran Islam.

Prosedur pembiayaan diperlukan agar bank syariah memperoleh keyakinan bahwa pembiayaan yang diberikan dapat dikembalikan oleh nasabahnya. Dalam pemberian pembiayaannya bank harus memperhatikan prinsip-prinsip pemberian pembiayaan dengan analisis $5 \mathrm{C}$, yaitu :

1. Character, untuk mengetahui sejauhmana itikad baik dan kejujuran calon nasabah untuk membayar kembali pembiayaan yang diterimanya.

2. Capacity, untuk melihat sejauhmana kemampuan calon nasabah dalam mengembalikan pokok pinjaman serta bagi hasilnya.

3. Capital, dalam hal ini biasanya bank tidak akan bersedia untuk membiayai suatu usaha $100 \%$ artinya bank harus mengetahui berapa banyak modal yang telah dimiliki calon nasabah, sehingga tidak seluruhnya mengandalkan pinjaman dari bank.

4. Condition of economy, dalam hal ini bank harus yakin bahwa kondisi ekonomi akan menunjang dan tidak menghambat kelancaran usaha yang akan dijalankan calon peminjam.

5. Collateral, yaitu jaminan apa yang dapat diberikan calon nasabah untuk tambahan pengamanan bagi 
bank atau pembiayaan yang diberikan.

Pada dasarnya, analisa pembiayaan dilakukan oleh bank syariah tidaklah berbeda dengan yang dilakukan oleh bank umum/konvensional. Aspek-aspek yang dinilai oleh pihak bank syariah didalam penilaian kebijakan pembiayaan sering disebut $5 \mathrm{C}$, sebagai pedoman dasar dalam pemberian kredit/pembiayaan yaitu Character, Capacity, Capital, Condition dan Collateral sebagaimana yang diuraikan di atas, serta bidang usaha sesuai dengan prinsip syariah. Hal tersebut bertujuan untuk melihat kondisi dan potensi pemohon dana. Dan akan diperoleh gambaran kekuatan dan kelemahan finansial perusahaan. Tanpa mengetahui kondisi keuangan calon penerima dana, maka resiko yang besar akan dihadapi oleh bank. Bahkan bila perusahaan memberikan pembiayaan dalam jumlah besar tanpa mengetahui kondisi keuangan penerima dana, dapat dikatakan ada sesuatu yang tidak benar dibalik pemberian pembiayaan tersebut.

Analisis pembiayaan merupakan langkah penting untuk realisasi pembiayaan di bank syari'ah. Analisis pembiayaan yang dilakukan oleh pelaksana (pejabat) pembiayaan di bank syari'ah dimaksudkan untuk :

1. Menilai kelayakan usaha calon peminjam;

2. Menekan resiko akibat tidak terbayarnya pembiayaan;dan

3. Menghitung kebutuhan pembiayaan yang layak.

Setelah tujuan analisis pembiayaan dirumuskan dan disepakati oleh pelaksana pembiayaan, maka untuk selanjutnya dapat ditemukan pendekatan-pendekatan yang digunakan untuk analisis pembiayaan. Dalam melaksanakan kebijakannya tersebut, analisis pembiayaan yang dikakukan seorang analis harus berpijak pada suatu prinsip. Prinsip adalah sesuatu yang dijadikan pedoman dalam melaksanakan suatu tindakan. Prinsip analisis pembiayaan adalah pedoman-pedoman yang harus diperhatikan oleh pejabat pembiayaan bank syari'ah pada saat melakukan analisis pembiayaan. Dengan memperhatikan ketentuan umum manajemen pembiayaan di bank syari'ah, ada beberapa aspek yang perlu diperhatikan dalam prosedur analisis pembiayaan.

\section{B. Analisis Penetapan Pemberian Pembiayaan melalui Metode Analitycal Hierarchy Process (AHP) di Bank Syariah}

multi kriteria yang kompleks menjadi suatu hirarki yang merupakan suatu representasi dari sebuah permasalahan yang kompleks dalam suatu struktur multi level dimana level pertama adalah tujuan, yang diikuti level faktor, kriteria, sub kriteria, dan seterusnya ke bawah hingga level terakhir dari alternatif. ${ }^{1}$

Hirarki yang dimaksudkan pada metode analisis di atas merupakan suatu masalah yang kompleks dapat diuraikan ke dalam kelompok-kelompoknya yang kemudian diatur menjadi suatu bentuk hirarki sehingga permasalahan akan tampak lebih terstruktur dan sistematis. Hierarki tingkat pertama yaitu hierarki puncak yang merupakan tujuan dari permasalaan yaitu pemilihan bank syariah. Pada hierarki tingkat kedua yaitu kriteria-kriteria mengenai hal-hal yang menjadi pertimbangan dalam menentukan atau memutuskan disetujui tidaknya suatau pengajuan pembiayaan pada bank syariah maupun solusi dari keputusan yang telah dibuat manajemen Bank Syariah tersebut.

Analisis AHP ini ditujukan untuk membuat suatu model permasalahan yang tidak mempunyai struktur, biasanya ditetapkan untukmemecahkan masalah yang terukur (kuantitatif), masalah yang memerlukanpendapat (judgement) maupun pada situasi yang kompleks atau tidak terkerangka, pada situasi dimana data, informasi statistik sangat minim atau tidak ada sama sekali dan hanya bersifat kualitatif yang didasari oleh persepsi, pengalaman atau pun intuisi. AHP ini juga banyak digunakan pada keputusan untuk banyak kriteria, perencanaan, alokasi sumber daya dan penentuan prioritas dari strategi-strategi yang dimiliki pemain dalam situasi konflik. ${ }^{2}$ Berikut ini merupakan bentuk model hirarki penelitian menggunakan Analitycal Hierarcy Process (AHP) :

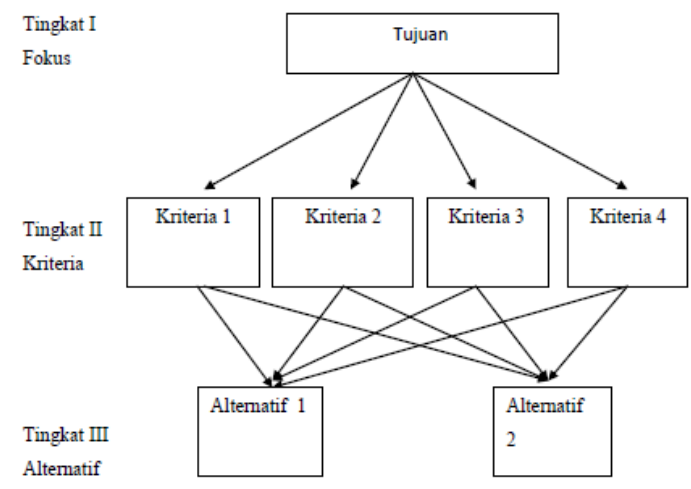

Gambar 1.1.

Bentuk Model Hierarki Penelitian

Berdasarkan skema hierarki di atas dapat difahami bahwa dalam AHP semua elemen pada suatu tingkat memiliki hubungan terhadap semua elemen yang ada pada tingkat berikutnya. Adapun keterangan menganai tingkatan dalam hierarki AHP di atas yang dikaitkan dengan proses analisa pembiayaan di bank syariah, Ahalliticklaphepfurgłk Phocess (A sebagai berikur :

1. Tingkat pertama : Tujuan keputusan (Goal), yaitu tujuan akhir yang telah ditetapkan manajemen bank syariah yaitu terwujudnya keputusan pemberian pembiayaan kepada calon nasabah sesuai dengan standar produk penyaluran pembiayaan di bank Syariah. 
2. Tingkat kedua : Kriteria-kriteria, yaitu kriteriakriteria mengenai hal-hal yang menjadi pertimbangan dalam melakukan analisa yang meliputi unsur-unsur penilaian pembiayaan. Terdapat empat unsur penilaian dalam hierarki di tingkat kedua ini yaitu :

a. Kriteria I yaitu : Karakter

b. Kriteria II yaitu : Kapasitas

c. Kriteria III yaitu : Modal

d. Kriteria IV yaitu : Jaminan

3. Tingkat ketiga : Alternatif pilihan, yaitu alternatif dari akad pembiayaan yang lain yang dimiliki bank syariah (dalam hal ini produk-produk pembiyaan yang ada di BRI Syariah KCP Ujungberung Kota Bandung

\section{HASIl PENELITIAN DAN ANALISA PEMBAHASAN}

Pada umumnya, masalah atau kendala yang terkait pada pengembangan ekonomi usaha kecil adalah permodalan, prospek pengembangan dan tantangannya, yang implikasinya terkait masalah dana atau pembiayaan. Islam, sebagai agama yang universal, tentu telah memiliki konsep tersendiri dalam mencari solusi dari masalah permodalan, pendanaan atau pembiayaan yang terkait ke dalam problematika pengembangan ekonomi mikro dan usaha kecil.

Kebijakan solusi yang ditawarkan ajaran Islam, pada hakekatnya hal ini didasari oleh nilai-nilai keadilan, kebersamaan dan kemaslahatan. Hal ini juga telah berusaha diterapkan pleh manajemen BRI Syariah KCP Ujungberung sebagaimana diuraian bab sebelumnya mengenai pelaksanaan pembiayaan yang dilakukan BRI Syariah sebagai lembaga intermediasi keuangan rakyat. Pleh karena itu, dalam menjalankan proses serta mekanisme penyaluran pembiayaannya tersebut, manajemen BRI Syariah menimplementasikan metode Analitycal Hierarchy Process (AHP) yang harus disesuaikan dengan ajaran Islam dalam bidang ekonomi dan keuangan.

Penggunaan metode Analitycal Hierarchy Process di BRI Syariah dapat secara sistemik membagi kriteria pembiayaan yang memenuhi standar dalam rangka pengejawantahan prinsip kehati-hatian (prudential principles) yang diatur UU Perbankan Syariah. Penerapan prinsip ini akan menjadi penting karena dengan prinsip bagi hasil (profit sharing), misalnya kegagalan perbankan syariah dalam memperoleh keuntungan yang wajar akan langsung berakibat berkurangnya bagi hasil yang diterima oleh masyarakat. Dengan demikian, maka dapat dikatakan bahwa penerapan Analitycal Hierarchy Process dalam kegiatan analisa pembiayaan di BRI Syariah KCP Ujungberung merupakan implementasi dari prinsip kehatihatian (prudential principles) tersebut, secara teknis dapat dijabarkan sebagai way of thinking, seni mengelola, mengendalikan, dan mengatasi trade off yang terjadi.
Berdasarkan uraian di atas, maka penulis menganalisa bahwa penggunaan metode Analitycal Hierarchy Process lebih lebih ditujukan bagaimana menekan trade off sampai pada batas seminimum mungkin. Karena prinsip ini tidak lain merupakan way of thinking pihak manajemen BRI Syariah KCP Ujungberung dalam usaha meminimalkan trade off antara risk and service. Oleh karena itu, prinsip ini harus built in dalam setiap proses yang secara detail dituangkan dalam bentuk sistem dan prosedur yang pada akhirnya melahirkan suatu kebijakan tertentu mengenai penyaluran pembiayaan di BRI Syariah KCP Ujungberung itu sendiri. Sehubungan dengan pelaksanaan analisa pembiayaan dengan metode Analitycal Hierarchy Process tersebut, maka terdapat bebrapa hal yang perlu diperhatikan jika ditinjau dari perspektif konsep ekonomi Islam. Dimana bagunan ekonomi Islam terdiri atas lima nilai universal yakni: tauhid (keimanan), 'adl (keadilan), nubuwwah (kenabian), khilafah (pemerintahan), dan ma'ad (hasil). Kelima nilai ini menjadi dasar inpirasi untuk menyusun teori ekonomi Islam.

Konsep nubuwwah dalam perspektif ekonomi Islam disini berkaitan dengan character dalam analisis 5C melalui penerapan Analitycal Hierarchy Process yang diterapkan oleh manajemen BRI Syariah KCP Ujungberung. Nubuwwah (kenabian) merupakan suatu bimbingan yang datang dari Allah melalui Nabi dan Rasul untuk mengajarkan kepada manusia bagaimana hidup yang baik dan benar didunia. Fungsi rasul adalah untuk menjadi teladan bagi manusia dengan diturunkannya Nabi Muhammad Saw dengan sifat-sifatnya yang harus diteladani oleh manusia dan para pelaku ekonomi.

Konsep Capacity dalam penerapan Analitycal Hierarchy Process pada analisa pembiayaan di BRI Syariah KCP Ujungberung yang menilai kemampuan calon nasabah dalam membayar hutang. Terkait hal tersebut, dalam sebuah hadist dijelaskan bahwa haram bagi seseorang mengambil harta orang lain (berhutang) namun dia tidak memiliki niat, motivasi, dan usaha untuk mengembalikannya sebagai berikut :

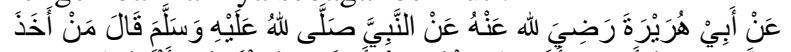

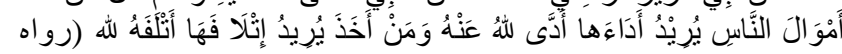

$$
\begin{aligned}
& \text { البخارى) }
\end{aligned}
$$

Dari Abi Hurairah semoga Allah meridoi, Dari Nabi Saw bersabda: Siapa yang mengambil harta manusia (berhutang) disertai maksud akan membayarnya maka Allah akan membayarkannya untuknya, sebaliknya siapa yang mengambilnya dengan maksud merusaknya (merugikannya) maka Allah akan merusak orang itu.3

Dari hadist di atas dapat dipahami bahwa membayar hutang adalah kewajiban bagi setiap yang berhutang. Dan tidak dibenarkan bagi orang (nasabah) yang mampu untuk menunda dalam membayar hutangnya. Islam menganjurkan untuk memberikan kemudahan yang

\footnotetext{
${ }^{3}$ Muhammad Ibn Ismail Al-Bukhariy, Shahih al-
} Bukhari Juz IIy, Dar Ibni Katsir, Beirut 1987, Hlm. 517. 
berhutang untuk memberikan tangguh bagi yang kesusahan serta menghapuskannya. Jika seorang debitur tidak menunaikan kewajibannya padahal ia sanggup untuk membayarnya maka Allah akan mengambil haknya. Adapun orang yang tidak sanggub membayar hutang maka semoga Allah mengampuninya.

Konsep Capital dalam penerapan Analitycal Hierarchy Process yang dilakukan BRI Syariah KCP Ujungberung menurut perpketif Ekonomi Islam merupakan modal atau harta disebut al maal ( المـال), secara harfiah adalah segala sesuatu yang engkau punya. Adapun dalam istilah syar'i harta diartikan sebagai sesuatu yang dimanfaatkan dalam perkara yang legal menurut hukum Islam seperti bisnis, pinjaman, konsumsi, dan hibah (pemberian). Islam mewajibkan setiap muslim, khususnya yang memiliki tanggungan untuk bekerja, bekerja merupakan suatu pokok yang memungkinkan manusia memiliki kekayaan. Rasulullah Saw bersabda tentang pentingnya modal yang artinya "tidak boleh iri selain kepada dua perkara yaitu: orang yang hartanya digunakan untuk jalan kebenaran dan orang yang ilmu pengetahuannya diamalkan kepada orang lain".

Sedangkan konsep collateral yang diterapkan dalam metode Analitycal Hierarchy Process di BRI Syariah KCP Ujungberung, dalam ekonomi Islam sama dengan Rahn dimana menurut bahasa berarti menggadaikan, menangguhkan - رهنا -رهنير هن atau jaminan (Borg)4 dan dapat juga dimaknai dengan alhabsu( الحبس رهن (Bisa etimologi rahn berarti tetap atau lestari, sedangkan alhabsu ( الحبس)berarti penahanan.5

Kemudian Konsep condition of economy atau kondisi ekonomi nasabah yang menjadi salah satu unsur penilaian pembiayaan di BRI Syariah KCP Ujungberung melalui sistem Analitycal Hierarchy Process dalam perpektif konsep ekonomi Islam merupakan penilaian dimana seorang pebisnis wajib untuk mempertahankan kelangsungan usahanya. Hal ini sebagaimana firman Allah SWT dalam Q.S. Al-Mulk ayat 15 sebagai berikut :

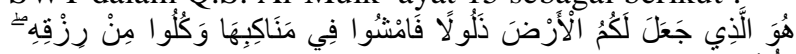

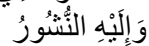

Dialah yang menjadikan bumi itu mudah bagi kamu, Maka berjalanlah di segala penjurunya dan makanlah sebahagian dari rezki-Nya. dan hanya kepada-Nya-lah kamu (kembali setelah) dibangkitkan.6

Dari ayat di atas dijelaskan bahwa setiap individu diberi kebebasan untuk bekerja di bumi Allah ini karena setiap manusia sudah diberikan kebebasan dalam mencari rezeki dan memperhatikan kelangsungan usaha sehingga memberikan dampak baik pada kondisi keuangan dan kesejahteraan keluarganya. Peran pemerintah dalam perekonomian terkadang memberikan dampak tersendiri bagi pelaku bisnis. Terkait hal tersebut, maka analisis terhadap aspek condition of economy dalam penggunaan metode Analitycal Hierarchy Process dilakukan melalui tahapan analisa yang meliputi analisis terhadap variabel makro yang melingkupi lembaga usaha yang diajalankan calon nasabah baik variabel regional, nasional, maupun internasional. Variabel yang diperhatikan terutama adalah variabel ekonomi walaupun tidak terlepas juga bank perlu memperhatikan variabel lainnya seperti kondisi politik, perundangan-undangan, dan lainya.

\section{KESIMPULAN}

Kesimpulan dari penelitian ini adalah penetapan penyaluran pembiayaan bagi nasabah di bank syariah diimplementasikan ke dalam penerapan prinsip kehatihatian dengan menggunakan unsur standar 5C dan prinsip ekonomi Islam seperti prinsip keterbukaan, kejujuran dan keadilan. Pelaksanaan analisis pembiayaan dengan metode AHP di BRI Syariah KCP Ujungberung dilakukan secara sistematis dan mengkrucut sehingga menghasil keputusan yang tepat, proporsional dan efisien. Serta Penetapan pemberian pembiayaan bagi nasabah dengan metode Analitycal Hierarchy Process (AHP) di BRI Syariah KCP Ujungberung secara umum telah sesuai dengan nilai-nilai dan prinsip-prinsi pekonomi dalam Islam yang meliputi keterbukaan, keadilan, kehati-hatian dan keterbukaan serta berbagai aspek yang terkait dengan kepentingan manusia dengan menyediakan untuk ketertiban kehidupan dan kesejahteraan (maslahah).

\section{DAFTAR PUSTAKA}

[1] Choiruman Pasaribu, Suhrawardi K. Lubis, Hukum Perjanjian Dalam Islam, Jakarta : Sinar Grafika, cet. 2, 1996.

[2] Dusuki, Asyraf Wajdi, Understanding The Objectives of Islamic Banking: A Survey Stakeholder Perspectives, International Journal of Islamic and Middle Eastern Finance and Management, Vol. 1, No.2, 2008.

[3] Mahmud Yunus, Kamus Arab Indonesia, Penerbit Yayasan Penyelengaraan Penterjemah Penafsir al-Qur'an, Jakarta: tahun 1989.

[4] Muhammad Ibn Ismail Al-Bukhariy, Shahih al-Bukhari Juz IIy, Dar Ibni Katsir, Beirut 1987.

[5] Saaty, Thomas L. "Mathematical Principles Of Decision Making The Complete Theory Of The Analytic Hierarchy Process". New york : University of Pittsburgh. 2007

[6] 